\title{
Linseed (Linum usitatissimum L.) Variety Adaptation at South western Ethiopia
}

\author{
Yechalew Sileshi $^{1}$, Mesfin Hailemariam ${ }^{1 *}$, Behailu Atero ${ }^{1}$, Abush Tesfaye ${ }^{2}$ \\ ${ }^{1}$ Jimma Agricultural Research Center, Ethiopian Institutes of Agricultural Research (EIAR), Jimma, Ethiopia \\ ${ }^{2}$ International Institutes of Tropical Agriculture, Oyo Road, Ibadan, Nigeria
}

*Corresponding Author: Mesfin Hailemariam, Jimma Agricultural Research Center, Ethiopian Institutes of Agricultural Research (EIAR), Jimma, Ethiopia

\begin{abstract}
This experiment was carried out using ten linseed varieties; conducted during the 2015/2016 and 2016/2017 main cropping season at Dedo, Semodo and Gech in South Western parts of Ethiopia. The experimental design was RCBD with three replications. Data were collected on eight quantitative morphological traits with the objectives of to test the performance of released linseed varieties on yield and yield related components at South Western parts of Ethiopia and to select well adapted varieties for the tested location. The across location analysis showed significant differences $(p<0.05)$ among varieties and locations $(p<0.05)$ for most of the parameters, including grain yield. However, the interactions; $\left(L^{*} V\right)$ and $\left(L^{*} V^{*} Y\right)$ showed non-significant differences. Mean grain yield ranged from 1.55 t/ha to 2.06 t/ha. The three high yielding varieties Blistar (2.06 t/ha), Kulumsa-1 (2.05 t/ha) and Jeldu (1.94 t/ha) are recommended for Dedo, Gechi and Somodo, and similar areas in Jimma, Buno Bedele and Ilu-Ababora zones. Therefore, these varieties have to be promoted to the farmer.
\end{abstract}

Keywords: Adaptation; Linseed; Released varieties

\section{INTRODUCTION}

Linseed or Flax, Linum usitatissimum L. is a diploid with $n=15$ chromosomes is member of linaceae family. Cultivated flax, Linum usitatissimum, is placed in the section Linum and has 30 diploid chromosomes [1,2] along with the proposed progenitors L. angustifolium and L. bienne, which share homostylous rather than heterosylous flowers. The origin of flax lies in southern Europe, the Near East, or Central Asia [3-5]. Ethiopia is considered as secondary center of diversity [6]. Linseed is distributed and produced in different parts of the world such as Canada, India, China, Kazakhstan, Russia, United States, Ethiopia and Europe. Kazakhstan Russia and Canada are the top three linseed producer countries while Ethiopia is seventh in linseed production in the world with total share of $3.5 \%$ of linseed production [7].

In Ethiopia the crop is best performs in altitudes ranging from 2200-2800 m.a.s.1; but it is also produced in areas as low as 1200 m.a.s.l and as high as 3420 m.a.s.l. It is an important rotational crop for cereals and pulses, in Ethiopia linseed has long history of cultivation by smallholders' farmers for household consumption manly used for its edible oil in Ethiopia [8]. However, the byproduct of linseed after oil extraction is used for animal feed [9]. Out of the total grain production coverage in Ethiopia $6.68 \%$ hectare of land was covered by oil seed crops from this linseed which shares a total area coverage of $0.62 \%$ ha $(79044.51$ ha); with a total production of 3233448.8 quintals and the national average yield is $11.16 \mathrm{t} / \mathrm{ha}$ [10] while, the productivity potential of Oromia regional state is as high as the national productivity which is 13.68 quintals per hectares [10]. From this South Western part of Ethiopia had immense potential for linseed production including Jimma, Buno Bedele and IluAbabora zones. Improvement in flax has lagged behind other oilseeds, including caster and soybean, in part because flax occupies a smaller niche as an oilseed and, consequently, received reduced resources for development. Genetic diversity within the crop is low and cannot be readily supplemented by intraspecific hybridization. Finally, methods of hybrid seed production have not been developed Several studies have been conducted on linseed regarding to the improvement of the crop. So far more than 17 varieties of linseed have been released in Ethiopia by national and regional research 
centers despite the fact that research efforts made resulted in a release of improved linseed varieties but farmers in the study area had no access to improved linseed, hence evaluating the performance of the released linseed varieties is of paramount significance to increase yield of the crop. To date in South Western part of Ethiopia, there is no performance evaluations study in released varieties of linseed in the past.

\section{OBJECTIVES}

\section{General objectives}

- To evaluate, select adaptable and acceptable linseed varieties in Southwestern parts of Ethiopia. Specific objectives

- To evaluate and promote released linseed varieties and (the performance of released linseed varieties around Jimma, Buno Bedele and Ilu-Ababora zones).

- To popularize and scaling up the most adaptable released linseed varieties in Southwestern Ethiopia.

\section{Materials ANd Methods}

\section{Experimental Treatments and Design}

\section{Description of the Study Areas}

This study was conducted at Dedo and Somodo districts in Jimma zone and Gechi district at Buno Bedele zone in Oromia Regional State of Ethiopia. Dedo is located $377 \mathrm{~km}$ from Addis Ababa, the altitude lies between 880 and 2400 m.a.s.1, with mean annual rainfall ranges between 1200 and $2800 \mathrm{~mm}$ and temperature minimum $20^{\circ} \mathrm{C}$ with maximum $25^{\circ} \mathrm{C}$ [11]. Somodo is located at $15 \mathrm{~km}$ from Jimma town and 368 from $\mathrm{km}$ Addis Ababa, lies between 1900 and 2050 m.a.s.l. It is

located between $7^{\circ} 46^{\prime \prime} 00^{\prime} \mathrm{N}-7^{\circ} 47^{\prime \prime} 00^{\prime} \mathrm{N}$ latitude and $36^{\circ} 44^{\prime \prime} 10^{\prime} \mathrm{E}-36^{\circ} 46^{\prime \prime} 50^{\prime}$ E longitude [12]. Gechi is located at $08^{\circ} 20 \mathrm{~N}^{\prime}$ latitude and $36^{\circ} 40 \mathrm{E}^{\prime}$ longitude and the elevation of the area was 1400-2380 m.a.s.l, it receives average rainfall of $1639 \mathrm{~mm}$ annually with average maximum temperature of $25.0^{\circ} \mathrm{C}$, and minimum of $18^{\circ} \mathrm{C}[13,14]$. The experiment consists of ten released linseed varieties (Table 1) obtained from Holeta Agricultural Research Center were used for this study.

\section{Experimental Design}

The treatments of was laid in a in randomized completed block design with three replications. The experiment was planted in 6 rows plot of $4 \mathrm{~m}$ length. The spacing used was $20 \mathrm{~cm}$ between rows and 5 $\mathrm{cm}$ within rows. The seed was drilled during planting and later thinned at $5 \mathrm{~cm}$ spacing. The fertilizer and seed rate were used as per the recommendation and all other recommended agronomic management practices were applied properly

Table1. Description of the origin, year of release, oil contents and seed color the linseed varieties used for this study.

\begin{tabular}{|l|l|l|l|l|l|}
\hline S No & Varieties & Origins & Oil Contents Year & of Seed Color \\
Release/Registrations & \\
\hline 1 & Tolle & CI-2698 x PGRC/E 13611/B & 36 & 2004 & Brown \\
\hline 2 & CI-1652 & Introduced from Europe & 37.06 & 1984 & Brown \\
\hline 3 & CI-1525 & Introduced from Europe & 36.52 & 1984 & Brown \\
\hline 4 & Jeldu & CI-1652 $\times$ Omega/23/A & 36.93 & 2010 & Brown \\
\hline 5 & Berene & PGRC/E 013627 & 37 & 2001 & Brown \\
\hline 6 & BILTSTAR & -- & NA & 2013 & -- \\
\hline 7 & Belay-96 & IAR/Li/124 × CI-25249(3)/4 & $36 . .3$ & $1996 / 97$ & Brown \\
\hline 8 & Chilalo & PGRC/E 200482/12 & 36.44 & 1992 & Brown \\
\hline 9 & Kulumsa-1 & Chilalo/16 & 37.1 & 2006 & Brown \\
\hline 10 & Bekoji-14 & -- & NA & 2014 & Brown \\
\hline
\end{tabular}

Sources: Ministry of Agriculture and Natural Resources, Holeta Agricultural Research center, NA=Not available.

\section{Data collection}

Data were collected both at plot and plant basis. The four central rows were used for data collection based on plots, such as days to flowering, days to maturity and 1000 seed weight. Five plants from the 
central rows were randomly selected for data collection on plant basis and the averages of the five plants in each experimental plot were used for statistical analysis for traits such as plant height, number of pods/ plants, number of seeds/plants; number of heads/plants; number of seeds/heads.

\section{Data analysis}

Analysis of variance was done using Proc GLM procedures of SAS Software after testing the ANOVA assumptions. Mean separations were estimated using Least Significant Difference (LSD) for the comparison among the experimental varieties at 0.05 probability level. Combined analysis of variance for both years and seasons was done to test the response of varieties to both environment and seasons after testing the homogeneity of the data.

\section{RESULTS AND DISCUSSION}

The combined analysis of variance across the three locations were presented in Table 2 . The mean square from the pooled analysis of variance over the three test locations showed highly significant location effects $(\mathrm{p} \leq 0.01)$ for all of the traits evaluated. The mean squares due to varieties revealed significant ( $\mathrm{p}$ $\leq 0.01$ ) differences for number of pods per plant, number of seeds/head and yield/ha. However, the interactions; $(\mathrm{L} * \mathrm{~V})$ and $(\mathrm{L} * \mathrm{~V} * \mathrm{Y})$ showed non-significant differences indicating consistent performance of varieties across locations. Based on the individual location, the highest seed yield was observed at Dedo from BILTSTAR Variety produced 2.57 t/ha followed by Bekoji-14 which produced $2.54 \mathrm{t} / \mathrm{ha}$, while the lowest yield was observed from variety Chilalo $1.59 \mathrm{t} / \mathrm{ha}$.

Table2. Mean square of combined analysis for linseed variety adaptation trial.

\begin{tabular}{|c|c|c|c|c|c|c|c|c|c|}
\hline $\begin{array}{l}\text { Source } \\
\text { variations }\end{array}$ & $\begin{array}{l}\text { of Degree } \\
\text { of } \\
\text { Freedom }\end{array}$ & $\begin{array}{l}\text { Days to } \\
\text { Maturity }\end{array}$ & $\begin{array}{l}\text { Plant } \\
\text { Height } \\
(\mathrm{cm})\end{array}$ & $\begin{array}{l}\text { Number } \\
\text { of } \\
\text { Pods/Plants }\end{array}$ & $\begin{array}{l}\text { Number } \\
\text { Seeds/Plan }\end{array}$ & $\begin{array}{l}\text { of Number of } \\
\text { tsHeads/Plants }\end{array}$ & $\begin{array}{l}\text { f Number } \\
\text { s Seeds/Heac }\end{array}$ & $\begin{array}{l}\text { of Thousand } \\
\text { ds Seed } \\
\text { Weight }\end{array}$ & $\begin{array}{l}\text { Yield }(\mathrm{t} \\
\text { ha-1) }\end{array}$ \\
\hline Var & 9 & $17.4 * *$ & $471.63 \mathrm{~ns}$ & $6.143^{*}$ & $12.05 \mathrm{~ns}$ & $3540.09 \mathrm{~ns}$ & $9.76^{*}$ & $1.07 * *$ & $0.40 * *$ \\
\hline Loc & 2 & $557.4 * *$ & $11592.87 * *$ & *25.20** & $44.93 * *$ & $21027.10 * *$ & $55.03 * *$ & & $6.62 * *$ \\
\hline loc*var & 18 & $1.36 \mathrm{~ns}$ & $254.19 \mathrm{~ns}$ & $2.75 \mathrm{~ns}$ & $5.53 \mathrm{~ns}$ & $2757.48 \mathrm{~ns}$ & $6.99 \mathrm{~ns}$ & & $0.20 \mathrm{~ns}$ \\
\hline Year & 1 & $0.02 \mathrm{~ns}$ & $760.55 \mathrm{~ns}$ & $18.08^{*}$ & $232.44 * *$ & $40242.41 * *$ & $108.26 * *$ & $0.0 \mathrm{~ns}$ & $28.52 * *$ \\
\hline year*loc & 2 & $0.03 \mathrm{~ns}$ & $1719.18 * *$ & $139.81 * *$ & $248.17 * *$ & $15981.96 * *$ & $44.45 * *$ & $0.00 \mathrm{~ns}$ & $15.38 * *$ \\
\hline year*var & 9 & $1.7 \mathrm{~ns}$ & 237.29ns & $2.02 \mathrm{~ns}$ & $6.78 \mathrm{~ns}$ & $2900.96 \mathrm{~ns}$ & $3.41 \mathrm{~ns}$ & $0.42 \mathrm{~ns}$ & $0.09 \mathrm{~ns}$ \\
\hline year*loc* & 18 & $0.33 \mathrm{~ns}$ & 348.49ns & $2.48 \mathrm{~ns}$ & $5.47 \mathrm{~ns}$ & $2754.30 \mathrm{~ns}$ & $6.39 \mathrm{~ns}$ & $0.16 \mathrm{~ns}$ & $0.16 \mathrm{~ns}$ \\
\hline
\end{tabular}

Remark: Var=variety, Loc=Location, ${ }^{* *}=$ significant at 0.01 probability level, ${ }^{*}=$ significant 0.05 probability level

The highest seed yield at Somodo was observed from Variety Jeldu produced $1.85 \mathrm{t} / \mathrm{ha}$ followed by BILTSTAR which produced $1.82 \mathrm{t} / \mathrm{ha}$, while the lowest yield was observed from variety Chilalo 1.52 $\mathrm{t} / \mathrm{ha}$ at Gechi the maximum seed yield was observed from Variety Jeldu produced $2.1 \mathrm{t} / \mathrm{ha}$ followed by BILTSTAR which produced $2.08 \mathrm{t} / \mathrm{ha}$, while the lowest yield was obtained from variety Chilalo 1.54 t/ha based on the two years data for 2015/16 and 2016/17 cropping season (Appendix Table 1). In general, Dedo was high yielder than somodo and Gechi (Table 3).

Table3. Combined mean yield and other parameters of linseed variety adaptation trial.

\begin{tabular}{|c|c|c|c|c|c|c|c|c|c|}
\hline Variety & $\begin{array}{l}\text { Days t } \\
\text { maturity }\end{array}$ & $\begin{array}{l}\text { Plant } \\
\text { height } \\
(\mathrm{cm})\end{array}$ & $\begin{array}{l}\text { Number } \\
\text { of }\end{array}$ & $\begin{array}{l}\text { Number } \\
\text { of }\end{array}$ & $\begin{array}{l}\text { Number of } \\
\text { heads/plants }\end{array}$ & $\begin{array}{l}\text { Number } \\
\text { of }\end{array}$ & $\begin{array}{l}\text { Thousand } \\
\text { seed weight } \\
\text { (gm) }\end{array}$ & $\begin{array}{l}\text { Yield } \\
\text { (tone/ }\end{array}$ & $\begin{array}{l}\text { Rank } \\
\text { based } \\
\text { on yield }\end{array}$ \\
\hline Tolle & 130.4 & 86.6 & 7.5 & 8.6 & 42.6 & 5.5 & 5.8 & 1.82 & 7 \\
\hline CI-1652 & 130.4 & 89.5 & 7.2 & 7.7 & 41.8 & 5.3 & 5.9 & 1.92 & 4 \\
\hline CI-1525 & 130.6 & 89.5 & 8 & 8.2 & 33.6 & 6.1 & 5.8 & 1.78 & 8 \\
\hline Jeldu & 131.9 & 90.9 & 7.5 & 8.4 & 39.5 & 6.2 & 5.9 & 1.94 & 3 \\
\hline Berene & 132.2 & 87.9 & 8.3 & 9.7 & 49.9 & 5.8 & 5.8 & 1.85 & 6 \\
\hline BILTSTAR & 130.6 & 83 & 6.5 & 6.8 & 26.9 & 6.7 & 6.5 & 2.06 & 1 \\
\hline Belay -96 & 131.2 & 85.9 & 8.5 & 8.9 & 79.7 & 6.8 & 5.9 & 1.77 & 9 \\
\hline Chilalo & 129.1 & 84.6 & 7.7 & 8 & 50.1 & 7.3 & 5.7 & 1.55 & 10 \\
\hline
\end{tabular}




\begin{tabular}{|l|l|l|l|l|l|l|l|l|l|}
\hline Kulumsa -1 & 132.1 & 88.3 & 7.1 & 7.4 & 45.4 & 7.1 & 5.8 & 2.05 & 2 \\
\hline BeKoji-14 & 131.6 & 101.6 & 7.7 & 8.1 & 49.2 & 7.4 & 5.7 & 1.87 & 5 \\
\hline Min. & 131 & 88.8 & 7.6 & 8.2 & 45.9 & 6.4 & 5.9 & 1.86 & - \\
\hline Max. & 129.1 & 83 & 6.5 & 6.8 & 26.9 & 5.3 & 5.7 & 1.55 & - \\
\hline Mean & 132.2 & 101.6 & 8.5 & 9.7 & 79.7 & 7.4 & 6.5 & 2.06 & - \\
\hline LSD (5\%) & 1 & 11.8 & 1.1 & 2 & 43.3 & 1.4 & 0.33 & 0.23 & - \\
\hline CV $(\%)$ & 1.15 & 19.2 & 19.1 & 32.17 & 30.8 & 26.1 & 8.48 & 18.7 & - \\
\hline
\end{tabular}

Based on the combined data over the three test locations the tallest plant height was recorded from BILTSTAR (101.6) and the shortest from Bekoji-14 (83) with mean value of 89.4 the maximum number of pods per plant was observed on the varieties Belay-96 (8.5) and the minimum from varieties BILTSTAR (6.5). Varieties Berene showed the largest number of seed (9.7), while varieties BILTSTAR showed the lowest number of seed (6.8). The highest of number of heads/plants was recorded from Belay-96 (79.7) whereas, the lowest number of heads/plants was observed from BILTSTAR (26.9). The highest number of number of seeds/heads was obtained from CI-1652 (7.6), while the lowest number of pods per plant was obtained from Bekoji-14 (5.3). Similarly, the maximum amount of yield was observed for varieties BILTSTAR (2.06 t/ha) and minimum for varieties Chilalo (1.55 t/ha).

\section{CONCLUSION}

Linseed is one of the most important oil crops in Ethiopia. To date, more than 17 improved linseed varieties was released at the national level. In the place where there is no improved variety accessible in the area, evaluating the performance of released varieties is a vital activity. Based on the present study result the performance of all the tested linseed varieties had superior in their productivity as compared to the national average. However, based on the combined data varieties BILTSTAR, Kulumsa-1 and Jeldu gave higher yield respectively. Therefore, in the future it is essential to demonstrate high yielder varieties to the farmer for production through extension and demonstrations.

\section{ACKNOWLEDGEMENT}

We thank the Ethiopian institutes of agricultural research for the fund and Holeta agricultural research centre highly acknowledged for providing the linseed improved varieties for the experiment.

\section{REFERENCES}

[1] Tammes T (1928) The genetics of the genus Linum. In: Lotsy JP, Goddijn WA (Eds.). Bibliographia Genetica. Martinus Nijhoff, The Netherlands pp: 1-34.

[2] Tutin TG, Heywood VH, Burges NA, Valentine DH (1980) Flora Europaea. Cambridge University Press, Cambridge, UK p: 480.

[3] Tammes T (1925) Mutation and evolution. Z. Induct. Abstamm. u.VererbLehre 36: 417-426.

[4] Helbaek H (1959) Domestication of food plants in the old world. Science 130: 365-372.

[5] Zeven AC (1982) Dictionary of cultivated plants and their centers of diversity, excluding ornamentals, forest tress and lower plants. center for agricultural publishing and documentation, Wageningen, The Netherlands p: 263.

[6] Adugna W (2007) Linseed (Linum usitatissimum L.). In: Vegetable oils and fats, plant resource of tropical Africa (PROTA). Vandervossen HAM, Kamilo GSM (Eds.). PROTA Foundation, Wageningen, Netherlands pp: 108-115.

[7] FAO (2017) FAOSTAT database: Agricultural crops. The Food and Agriculture Organization of the United Nations, USA.

[8] Hiruy B, Nigussie A (1988) Verification of improved linseed production practices on farmers' fields. In Oil crops: sunflower, linseed and sesame. Proceedings of the fourth oil crops network workshop, Njoro, Kenya.

[9] Alemayehu N, Alemaw G (1997) Highland Oil crops: A two-decade research experience in Ethiopia.

[10] CSA (2017) Agricultural samples survey 2017/18. Report on area and Production of crops, central statistics authority, Addis Ababa, Ethiopia.

[11] Gemechu A (2016) Estimation of soil loss using revised universal soil loss equation and determinants of soil loss in Tiro Afeta and Dedo Districts of Jimma Zone, Oromia National Regional State, Ethiopia. Trends in Agricultural Economics 9: 1-12. 
[12] Hailu L (2018) Effects of level soil bund on Selected soil physicochemical properties in Somodo Watershed, Jimma Zone, South-Western Ethiopia.

[13] Kebede M (2018) Distribution of wheat head blight, Identification and Characterization of Associated Fusarium species in southwestern Ethiopia.

[14] Gomez KA, Gomez AA (1984) Statistical procedures for agricultural research. John Willey and Sons, New York,USA.

Citation: Mesfin Hailemariam, Et.al., "Linseed (Linum usitatissimum L.) Variety Adaptation at South western Ethiopia", International Journal of Forestry and Horticulture (IJFH), vol. 5, no. 4, pp. 41-45, 2019. Available: DOI: http://dx.doi.org/ 10.20431/2454-9428.0504005

Copyright: () 2019 Authors. This is an open-access article distributed under the terms of the Creative Commons Attribution License, which permits unrestricted use, distribution, and reproduction in any medium, provided the original author and source are credited. 